\title{
Muhasebe Meslek Mensuplarının Kurumsal Yönetim Algı Düzeylerinin Ölçülmesine Yönelik Ankara İlinde Bir Araştırma
}

\author{
A Study on Measuring Bookkeeping Professional Members' Perception \\ Levels of Corporate Governance in Ankara Province
}

\section{Dr. Tuğba Dölen}

\section{Öz}

Bu çalışmanın amacı, 3568 sayılı Serbest Muhasebeci Mali Müşavirlik ve Yeminli Mali Müşavirlik Kanun'unda belirtilen muhasebe meslek mensuplarmin, muhasebe mesleğini yerine getirmeleri sirasında kurumsal yönetim kavramını ne ölçüde algıladıklarını tespit etmektir. Ayrica, muhasebe meslek mensuplartnin mesleki tecrübeleri ile kurumsal yönetim uygulamaları hakkında bilgi sahibi olmaları arasındaki ilişki analiz edilmeye çalışlacaktır. Çalışmada öncelikle kurumsal yönetim kavramı ve ilkeleri hakkında genel bir bilgi verilmiş, daha sonra muhasebe uygulamalarmin kurumsal yönetim üzerindeki etkileri ortaya konulmaya çalışılmıştır. Çalışmanın amacına ulaşmak için alan araştırması yöntemi kullanılmıştır. Araştırmanın amacından yola çıkılarak yürütülen alan araştırmasinda anket tekniği ile veri toplanmıştır. Araştırmada, anket formunda yer alan her bir sorudaki her bir cevap seçeneğine karşıllk gelen bir kod atanarak, geri dönen anket formundaki cevaplar kodlanmıştır. Kodlanan cevaplar, "SPSS (Statistical Package For Social Sciences) For Windows 15.0 Sürümü" ve ilişki analizinde Ki Kare Testi kullanılmıştır.

Anahtar Kelimeler: Kurumsal Yönetim, Kurumsal Yönetim İlkeleri, Muhasebe Mesleği

\footnotetext{
Abstract

Objective of this study is to identify to what extent bookkeepers, which are defined in law no. 3568 Independent Accountant and Financial Advisor - Certified
}

Financial Advisors Act, perceive the term "Corporate Governance" while they are practicing their professions. Besides, the relationship between bookkeepers' professional experience and their knowledge on corporate governance applications will be analyzed. First of all, general information is presented on the corporate governance term and its principles and then effects of bookkeeping practices on corporate governance term are explored in the study. To achieve the goal of the study, field research method is used and data is gathered using questionnaire technique. Each response option of each question on questionnaire form is coded with specific inference and returning questionnaire forms are evaluated. Coded forms are evaluated via SPSS (Statistical Package For Social Sciences) for Windows Ver. 15.0 and Chi Square Test is applied for correlation analysis.

Keywords: Corporate Governance, Corporate Governance Principles, Bookkeeping Profession

\section{Giriş}

Finansal küreselleşmenin hız kazandığı günümüzde farklı ülkelerde yaşanan finansal krizlerin arkasında, kamunun ve özel sektör işletmelerinin kurumsal yönetim politikalarının eksikliği yatmaktadır. $\mathrm{Bu}$ nedenle kurumsal yönetim kavramı tüm işletme disiplinlerini kapsayacak şekilde gittikçe artan bir önem arz eder duruma gelmiştir. Gelişmiş ülkeler ve uluslararası finans kuruluşları bu konuya büyük önem vermeye başlamışlardır. Bu kuruluşlar yatırım

Dr. Tuğba Dölen, Gazi Üniversitesi Polatlı Sosyal Bilimler Meslek Yüksekokulu, tdolen@gazi.edu.tr

* Bu çalışma yazarın "Muhasebecilerin Kurumsal Yönetim Konusundaki Sorumlulukları" isimli doktora tezinden türetilmiştir 
yapmadan veya kredi tahsis etmeden önce kurumsal yönetim uygulamalarının kalitesini gözetir hale gelmişlerdir (Poyraz, 2005, s. 158).

Kurumsal yönetim; şirket yöneticileri, çalışanları ve hissedarları arasında uyum sağlayan bir kurum kültürüdür. Bu uyum, başta muhasebe departmanı olmak üzere, şirketin tüm departmanlarında kendini göstermektedir. İyi bir kurumsal yönetimin temel prensipleri; adil davranma, sorumluluk, hesap verebilirlik, kamuyu aydınlatma ve şeffaflıktır. Bu prensiplere adapte olan muhasebe meslek mensupları, şirketin hedeflerine ulaşmasında ve daha etkili performans göstermesinde etkili olacaktır.

İşletmelerde etkili bir kurumsal yönetim sisteminin kurulup geliştirilmesi büyük ölçüde muhasebe meslek mensuplarının kurumsal yönetim ilkelerine uyumu ile mümkündür. Muhasebe meslek mensuplarının kurumsal yönetim algı düzeylerini tespit etmek, kurumsal yönetim sisteminin uygulanabilirliğine katkı sağlamaktadır.

\section{Kurumsal Yönetim Kavramı ve İlkeleri}

2002 yllında Türk Sanayici ve İşadamları Derneği (TÜSİAD) tarafından hazırlanan raporda kurumsal yönetim kavramı, en geniş anlamda modern yaşamda insanların bir amaca ulaşmak için oluşturduğu herhangi bir kurumun yönetiminin düzenlenmesidir. Daha dar anlamda ise, bir kurumun beşeri ve mali sermayesini çekmesine, etkin çalışmasına ve böylece ait olduğu toplumun değerlerine saygı gösterirken uzun dönemde ortaklarına ekonomik değer yaratmasına imkân tanıyan her türlü kanun, yönetmelik, kod ve uygulamaları ifade etmektedir (TÜSİAD, 2002, s. 9).

Ekonomik İşbirliği ve Kalkınma Örgütü (OECD) Kurumsal Yönetim Komitesine göre kurumsal yönetim, geniş anlamda, şirketlerin yönlendirildiği ve kontrol edildiği sistem olarak tanımlanabilir ve esasen şirket yönetimi, yönetim kurulu, hissedarları ve diğer çıkar grupları arasındaki ilişkiler dizisini içerir. Kurumsal yönetim, şirketlerin amaç ve hedeflerinin saplandığ 1 ve bunlara erişebilmek için performansı izleme araçlarının belirlendiği yapıyı ortaya koyar. Kurumsal yönetim, şirketlerin yönetimi ve denetimini sağlayan dâhili araçlarla ilgilidir. Hükümetler her bir kurumsal yönetim sisteminin içinde geliştiği yasal, kurumsal ve düzenleyici iklimi biçimlendirmede merkezi bir rol oynamakta, ama asıl sorumluluk özel sektöre düşmektedir (OECD, 2004, s.9).

Bir başka tanıma göre kurumsal yönetim, üç üçgen olarak adlandırmakta ve bir yandan işletme üst yönetiminin amaca uygun fonksiyonel bir yapılandırılmasını amaçlamakta, diğer yandan yöneticinin sevk ve yönetim işlevini ve denetçilerin denetim işlevleri arasında denge sağladığını vurgulanmaktadır (Pulaşl, 2003, s. 5).

Uluslararası yazında yapılacak bir literatür taramasında güncel çalışmaların dikkati çekmekte olduğu görülebilecektir. Bunlar arasında 2005 yılinda Luo'nun kurumsal yönetimi, işletmenin stratejik yönlendirmesini ve performansını açılayan ve kontrol eden, şirket ve paydaşları arasındaki ilişkiler bütünü şeklinde açıklamakta olduğu dikkati çekmektedir. Ayrıca 2004 yılında Hoskinson, Yiu ve Kim’in çalışmalarında yönetim kavramının bir sistem olarak küresel arenada rekabet avantajına yol açabileceğine işaret ettikleri görülmektedir. Öte yandan 2001 y1lında Sloan'un ise kurumsal yönetim yaklaşımının, işletmenin yönetimsel ve finansal alanları arasındaki ayrilıkların yarattığı performansı zedeleyen problemlerin çözülmesini destekleyen bir mekanizma olarak tanımlandığı görülmektedir (Kayacan, 2006, s. 46).

Kurumsal yönetimi ekonomik büyüme ve finansal kararlılık için hayati önemde faktör olarak gören Aguilera 2005 yılında, kurumsal yönetim çabalar1nın işletme sahipleri, sahipleri temsil edenler ve ç1kar grupları arasında dengenin kurulmasına dayalı kurumsal kültürün etkinliğinin ilerletilmesi yönünde verilmesi ve bu konunun "sürdürülebilir kurumsal yönetim modeli” çerçevesinde ele alınması gerektiğini vurgulamaktadır (Aguilera, 2005, s. 39).

Çalışmada esas aldığımız kendi tanımımıza göre, kurumsal yönetim; şirket yöneticileri, çalışanları ve hissedarları arasında uyum sağlayan bir kurum kültürüdür. Bu uyum, başta muhasebe departmanı olmak üzere, şirketin tüm departmanlarında kendini göstermektedir. İyi bir kurumsal yönetimin temel prensipleri; adillik, sorumluluk, hesap verebilirlik ve şeffaflıktır. Bu prensiplere adapte olan şirket yöneticileri, şirketin hedeflerine ulaşmasında ve daha etkili performans göstermesinde etkili olacaktır. 
Ülkelerde ortaya çıkan ekonomik krizler ve şirketlerde oluşan skandallar nedeniyle şirketlere olan güvenin yeniden kazanılması amacıyla kurumsal yönetim ilkeleri hazırlanmıştır. Kurumsal yönetim ilkelerinin hazırlanmasında birçok ülkenin düzenlemeleri incelenerek 1999 yılında Ekonomik İşbirliği ve Kalkınma Örgütü (OECD), kurumsal yönetim ilkelerini yayınlamıştır. Bu ilkeler; hissedarların hakları, hissedarların adil muamele görmesi, doğrudan çıkar sahiplerinin rolü, kamuoyuna açıklama yapma ve şeffaflık ve yönetim kurulunun sorumlulukları şeklinde beş ana başlık altında toplanmıştır. Benzer biçimde; Sermaye Piyasası Kurulu (SPK), ülkemizin kendine özgü koşullarını inceleyerek kurumsal yönetim ilkelerini belirlemiş, 2003 yılında açıklamıștır. SPK, kurumsal yönetim ilkelerini pay sahipleri, kamuyu aydınlatma ve şeffaflık, menfaat sahipleri ve yönetim kurulu olarak dört ana başlık altında toplamıştır.

SPK tarafından hazırlanan bu ilkeler Şubat 2005'de gözden geçirilerek yenilenmiştir. Hem OECD’nin hem de SPK'nın kurumsal yönetim ilkeleri dikkate alınarak, genel kabul gören tüm uluslararası kurumsal yönetim yaklaşımlarında, adil davranma, kamuyu aydınlatma ve şeffaflık, hesap verebilirlik ve sorumluluk kavramları olmazsa olmaz kavramlar olarak karşımıza çıkmakta ve bu kavramlar genel kabul görmüş kurumsal yönetim ilkeleri olarak sıralanmaktadır.

Adil davranma ilkesi, farklı çıkar sahiplerinin farklı ve birbirini dışlayacak nitelikteki çıkarları arasında bir dengenin sağlanmasını ifade etmektedir. Bu ilke, şirket yöneticilerinin alınacak kararlardan etkilenecek tüm kesimlere eşit uzaklıkta olmasını ve sadece belirli bir kesimin değil, şirketin varlığını sürdürmesi için gerekli tüm tarafların haklarının gözetilmesini ifade etmektedir (Doğan, 2007, s. 50-51). Adil davranma ilkesi, OECD tarafindan hazırlanan kurumsal yönetim ilkelerinde hissedarın adil muamele görmesi, SPK tarafından hazırlanan kurumsal yönetim ilkeleri ile ilgili düzenlemelerde ise eşitlik ilkesi olarak ele alınmıştır.

Şeffaflık; kredilerin yatırımcılarca kullanımı, kredi kullananların kredibilitesi, hükümetin kamu hizmetlerini sunumu ve uluslararası kuruluşların faaliyetleri hakkında doğru zamanlı ve güvenilir ekonomik, sosyal ve politik bilginin artan biçimde akışının sağlanması olarak tanımlanmaktadır (Tuzcu, 2004, s.18). Kamuyu aydınlatma ise ortaklık pay sahipleri ve alacaklarının menfaatlerini korumaya ve haklar1- nı bilinçli ve etkili şekilde kullanmaya yardım eden, gelecekteki pay ve tahvil sahiplerinin ve sermaye piyasasının diğer ilgililerinin aldatılmalarını önleyip ortaklık yararına kazanılmalarını sağlayan, özel ekonomik gücün, milli iktisadın gereklerine ve faydasına uygun çalışmasını gerçekleştiren, gerek iç, gerek dış denetimi kapsamı içine alan ilkelerin bütünü olarak tanımlanmaktadır (Özkan, vd., 2008, s. 62).

SPK kurumsal yönetim ilkelerinde hesap verebilirlik; "yönetim kurulu üyelerinin esas itibarıly anonim şirket tüzel kişiliğine ve dolayısıyla pay sahiplerine karşı olan hesap verme zorunluluğu" olarak tanımlanmıştır (SPK, 2005, s.3). Hesap verebilirlik ilkesinin bulunmadığ 1 bir şirkette finansal tabloların ve faaliyet raporlarının gerçeği yansıtması beklenemez.

Sorumluluk ilkesi ise, işletme yönetimince alınan kararların ve gerçekleştirilen eylemlerin hukuk kuralları ile toplumsal ve ahlaki değerlere uygunluğunu ve denetlenmesini ifade eder (Daştan, 2010, s. 9). SPK kurumsal yönetim ilkelerinde sorumluluk; "şirket yönetiminin anonim şirket adına yaptığı tüm faaliyetlerinin mevzuata, esas sözleşmeye ve şirket içi düzenlemelere uygunluğunu ve bunun denetlenmesi” olarak tanımlanmıştır (SPK, 2005, s. 3). Bu ilke ile şirket yönetiminin sahip olduğu yetkileri kullanarak yaptıkları eylemlerin sonuçlarından sorumlu tutulabilmelerini ifade etmektedir.

\section{Muhasebe Uygulamalarının Kurumsal Yönetim Üzerindeki Etkileri}

Muhasebe uygulamalarının temel amacı, işletmenin faaliyetleri ile ilgili verileri toplamak ve kaydetmektir. Kaydedilen bu bilgilerin doğru ve güvenilir olması genel kabul görmüş kurumsal yönetim ilkelerinden adil davranma ilkesi gereği, işletme ile ilgisi bulunan tüm tarafların haklarının korunmasını sağlar.

Kurumsal yönetim sistemi; işletmelerde, bir yandan ekonomik ile sosyal hedefler arasında, öte yandan işletme topluğunun hedefleri ile içinde çalışan kişilerin hedefleri arasında dengenin kurulmasını sağlamak amacıyla alınabilecek önlemlerden ve bu önlemlerin, kullanılmasını zorunlu kıldığı, insan kaynakları, cihazlar, yöntem ve prosedürlerin tümünden oluşur (Aysan, 2007, s. 82). Bu kapsamda kurumsal yönetim işletme varlık ve değerlerini yönetenlerin hesap verecek durumda bulunmalarını amaçlamaktadır. Hesap verebilirlik ise muhasebe meslek mensuplar1- 
nın görevlerinden olan etkin finansal raporlama ile mümkündür. Şeffaf bir şekilde düzenlenen finansal tablolar, şirket yönetiminin aldığı kararların ve yapılan faaliyet sonuçlarının sorgulanmasını sağlayabilir.

İşletmelerde kurumsal yönetim anlayışını hayata geçirebilecek yönetim ve denetim kurulları muhasebe bilgi sisteminden destek sağlama ihtiyacı içerisindedirler. İşletme sürekliliğinin sağlanması, uzun süreli kârlı ve sağlıklı büyümenin güven altına alınabilmesi ile kurumsal yönetim sisteminin olușturulması ve devamlılığın sağlanması büyük ölçüde muhasebe bilgi sisteminden sağlanan bilgiler ile mümkün olabilmektedir (Daştan, 2010, s. 10).

Kurumsal yönetim ile muhasebe bilgi sistemi arasında çok güçlü bir bağ vardır. Bu anlamda, yönetimin sorumluluklarını yerine getirmeleri ve işletme performansı hakkında yatırımcılara bağımsız bilgiler sunma işlevi muhasebe bilgi sistemine aittir. Muhasebede yer alan maliyet, güvenilirlik, tahakkuk esası ve ihtiyatlllık gibi kavramlar kurumsal yönetim felsefesinde de yer almaktadır (Sloan, 2001, s. 341-342). Bu nedenle, bilgi kaynaklarının doğru temin edilmesi ve etkin kullanımı kurumsal yönetimin uygulanabilirliğini güçlendirmektedir. Bilgi kaynaklarının güvenilir, adil, doğru ve şeffaf nitelikleri taşıması muhasebe departmanının sorumluluğundadır. İşletmelerde kurumsal yönetim anlayışının benimsenmesi için hızla değişen bilgilerin üretilmesi gerekmektedir. Bu bilgiler ise muhasebe bilgi sistemi tarafindan sağlanmaktadır. O halde muhasebe bilgi sistemi ve kurumsal yönetim anlayıșı etkin bir yönetim için karşılıklı etkileşim içerisindedir.

Muhasebe bilgilerinin üretim sürecinde, evrensel niteliğe sahip, muhasebenin temel kavramlarından sosyal sorumluluk kavramı gereği muhasebenin en önemli sorumluluğu; işletmenin faaliyet sonuçları ve finansal durumu hakkında ilgililere güvenilir ve doğru bilgiler sağlamaktır. Sosyal sorumluluk kavramından hareketle kurumsal yönetim, işletme yönetimi ve muhasebe uzmanlarının toplumun güvenini yeniden kazanabilmek amacıyla ortaya çıkardıkları bir bilgi ve denetim sistemi olarak karşımıza çıkmaktadır (Atabey vd., 2005, s. 239-240).

Doğru kurumsal yönetimin kriterlerinden biri olan şeffaflık ve kamuyu aydınlatma için OECD, "şirket tarafından yapılan açıklamaların şirketin gerçek finansal durumunu ve faaliyet sonuçlarını içermesi gerektiğini" belirtir. Bu konudaki en doğru bilgi kaynağı; bilanço, gelir tablosu, nakit akım tablosu ve finansal tablo dipnotları ve açılklamaları gibi denetimden geç- miş mali tablolardır (Darman, 2008, s.71). Kamuya sunulacak bilgiler, mutlaka muhasebe standartlarına, mali ve mali olmayan denetime uygun olarak açıklanmalıdır. Bu mali tabloları Uluslararası Finansal Raporlama Standartları (UFRS) ve Uluslararası $\mathrm{Mu}-$ hasebe Standartları'na (UMS) göre hazırlayarak, doğru zamanda kamuoyuna sunma sorumluluğu muhasebe departmanına aittir.

\section{Araştırmanın Amacı ve Yöntemi}

Bu çalışma, 3568 sayılı Serbest Muhasebeci Mali Müşavirlik ve Yeminli Mali Müşavirlik Kanunu’nda belirtilen muhasebe meslek mensuplarının kurumsal yönetim kavramını ve ilkelerini ne ölçüde algıladıklarını tespit etmek amacıyla gerçekleştirilmiştir.

Araştırmada, Ankara ilinde faaliyet gösteren muhasebe meslek mensuplarının kurumsal yönetim algı düzeylerini tespit etmek amacıyla alan araştırması yöntemi kullanılmıştır. Araştırmanın temel amacından yola çıkılarak yürütülen alan araştırmasında veri toplama aracı olarak anket tekniği kullanılarak belirlenen değişkenlere ilişkin sorular oluşturulmuştur. Anketler gözlem birimlerine e-posta yoluyla gönderilerek, veriler toplanmıştır. Anket çalışmasında soru içeriğinin cevaplayıcı tarafından açıkça görülmesini sağlaması ve cevaplayıcılar arasında karşılaştırma yapılabilmesi amacıyla kapalı uçlu soru türünden yararlanılmıştır.

Araştırmayla ilgili verilerin toplanmasında iki bölümden oluşan bir anket formundan yararlanılmıştır. Anket formundaki birinci bölümde, muhasebe meslek mensupları hakkında tanımlayıcı bilgi sağlamak amaçlanmıştır. Bu amaçla; kişilerin çalışma durumu, mesleki unvanları, eğitim durumu ve tecrübeleri ile ilgili sorular hazırlanmıştır. İkinci bölümde; muhasebe meslek mensuplarının kurumsal yönetim uygulaması hakkındaki bilgi düzeylerini ölçmeye yönelik sorular yer almaktadır. Bu sorular; muhasebe meslek mensuplarının kurumsal yönetim kavramına ilişkin algı̈ düzeylerini belirlemeye yöneliktir.

\section{Araştırmanın Ana Kütlesi ve Örneklem Seçimi}

Araştırmada, Ankara ilinde faaliyet gösteren Serbest Muhasebeci, Serbest Muhasebeci Mali Müşavir ve Yeminli Mali Müşavir olarak 3568 sayılı kanunla muhasebe mesleğini icra edenlerin tamamı ana kütleyi oluşturmaktadır. Araştırmanın ana kütlesini oluştu- 
ran Serbest Muhasebeci, Serbest Muhasebeci Mali Müşavir ve Yeminli Mali Müşavirlerin sayıları, Türkiye Serbest Muhasebeci Mali Müșavirler ve Yeminli Mali Müşavirler Odalar Birliğine (TÜRMOB) bağlı ilgili meslek odalarından öğrenilmiștir. Araștırmanın ana kütlesini oluşturan, Ankara meslek odalarına kayıtlı muhasebe meslek mensupları Tablo 1' de gösterilmektedir.

\section{Tablo 1. Araştırmanın Ana Kütlesini Oluşturan Meslek Mensupları}

\begin{tabular}{|l|c|}
\hline \multicolumn{1}{|c|}{ Mesleki Unvanlar } & Ana \\
Kütle \\
\hline Serbest Muhasebeci & 1847 \\
\hline Serbest Muhasebeci Mali Müşavir & 8570 \\
\hline Yeminli Mali Müşavir & 1176 \\
\hline Toplam & $\mathbf{1 1 5 9 3}$ \\
\hline
\end{tabular}

Araştırmanın amaçlarına en uygun örneklem hacminin belirlenebilmesi için; n, örneklem hacmi; N, evren hacmi; z, güvenilirlik düzeyine ait tablo değeri, $\mathrm{p}$ ve $\mathrm{q}$ sırasıyla ilgilenilen olayın görülme ve görülmeme olasılıkları ve d, duyarlılık düzeyi olmak üzere, $n=\left[N \cdot z^{2} \cdot p \cdot q\right] /\left[N \cdot d^{2}+z^{2} \cdot p \cdot q\right]$ formülü kullanılmıştır (Esin vd., 2010, s. 117).

$\mathrm{Bu}$ formüle göre; \%95 güvenilirlikle $\mathrm{N}=11593$, $\mathrm{z}=1,96, \mathrm{p}=\mathrm{q}=0,5$, ve $\mathrm{d}=0,05$ alınarak en uygun örneklem hacmi $n=372$ olarak hesaplanmıştır. Gözlem birimlerinin anketi cevaplamama durumu ve geçersiz sayılacak anketler düşünülerek örneklem hacmi 450 olarak belirlenmiştir.
Araştırmanın ana kütlesini oluşturan 11593 meslek mensubundan 450 meslek mensubu basit tesadüfî örnekleme yöntemine göre seçilmiştir. 35 meslek mensubu anketi cevaplamamıştır. 11 anket ise geçersiz sayılmıştır. Bu nedenle, analizler 404 anketten elde edilen veriler üzerinden gerçekleştirilmiştir.

\section{Araştırmanın Analizi ve Değerlendirilmesi}

Araştırmada, anket formunda yer alan her bir sorudaki her bir cevap seçeneğine karşılık gelen bir kod atanarak, geri dönen anket formundaki cevaplar kodlanmıştır. Kodlanan cevaplar, "SPSS (Statistical Package For Social Sciences) For Windows 15.0 Sürümü” ile analiz edilmiştir.

Bu bölümde araştırmaya katılan Ankara ilindeki Serbest Muhasebeci, Serbest Muhasebeci Mali Müşavir ve Yeminli Mali Müşavirlerin anket sorularına vermiş oldukları bilgiler, istatistiksel analizleri tablolar yardımıyla açıklanacaktır. Bu inceleme sırasında araştırmanın amacına yönelik oluşturulan "Muhasebe meslek mensuplarının mesleki tecrübeleri ile kurumsal yönetim uygulamaları hakkında bilgi sahibi olma durumları arasında ilişki yoktur.” şeklindeki yokluk hipotezi test edilecektir.

Araştırma bulgularının değerlendirilmesine ilk olarak, araștırmaya katılan muhasebe meslek mensupları hakkında genel bilgiler verilecektir. Anket formunu cevaplayan muhasebe meslek mensuplarının çalışma durumu Tablo 2' de görülmektedir. Buna göre; cevaplayıcıların 98'inin bağımlı muhasebeci, 301'inin de bağımsız muhasebeci olduğu tespit edilmiştir.

Tablo 2. Araştırma Katılanların Çalıșma Durumları

\begin{tabular}{|l|l|l|}
\hline \multicolumn{1}{|c|}{ Çalışma Durumu } & \multicolumn{1}{|c|}{ Sayı } & \multicolumn{1}{|c|}{ Yüzde } \\
\hline Bağımlı Muhasebeci & 98 & 24,3 \\
\hline Bağımsız Muhasebeci & 301 & 74,5 \\
\hline Cevapsız & 5 & 1,2 \\
\hline Toplam & $\mathbf{4 0 4}$ & $\mathbf{1 0 0}$ \\
\hline
\end{tabular}


Tablo 2 incelendiğinde cevaplayıcıların büyük çoğunluğunu, $\% 74,5$ 'lik oranla bağımsız olarak çalışan muhasebeciler, \%24,3'lük oranla ise bağımlı olarak çalışan muhasebeciler oluşturmaktadır. Araştırmaya katılanların \%1,2'si çalışma durumunu belirtmemiştir.

Araştırmaya katılanların mesleki unvanlarına ilişkin bilgiler Tablo 3?' de görüldüğü gibidir. Araştırmaya katılanların; 64'ü Serbest Muhasebeci, 262'si Serbest
Muhasebeci Mali Müşavir ve 74’ü Yeminli Mali Müşavirdir. Tablo 3 incelendiğinde \%64,9'luk bir oranla Serbest Muhasebeci Mali Müşavirin ankete en çok cevap veren kişi olduğu görülmektedir. Daha sonra sırasıyla \%18,3'lük oranla Yeminli Mali Müşavir, \%15,8'lik oranla Serbest Muhasebeci gelmektedir. \%1 oranla araştırmaya katılanlar, mesleki unvanlarını belirtmemiştir.

Tablo 3. Araştırmaya Katılanların Mesleki Unvanları

\begin{tabular}{|c|c|c|}
\hline Mesleki Unvanı & Sayı & Yüzde \\
\hline Serbest Muhasebeci & 64 & 15,8 \\
\hline Serbest Muhasebeci Mali Müşavir & 262 & 64,9 \\
\hline Yeminli Mali Müşavir & 74 & 18,3 \\
\hline Cevapsız & 4 & 1 \\
\hline Toplam & $\mathbf{4 0 4}$ & $\mathbf{1 0 0}$ \\
\hline
\end{tabular}

Araştırmaya katılan muhasebe meslek mensuplarının mesleki tecrübelerine ilişkin bilgiler Tablo 4' de yer almaktadır. Buna göre; araştırmaya katılan muhase- be meslek mensuplarından 45 'i 2-5 yıl, 74'ü 5-10 yıl, 137 'si $10-20$ yil ve 146 's 20 yil ve daha fazla muhasebe mesleğini icra etmektedir.

Tablo 4. Araştırmaya Katılanların Mesleki Tecrübeleri

\begin{tabular}{|l|l|l|}
\hline \multicolumn{1}{|c|}{ Mesleki Tecrübe } & Sayı & \multicolumn{1}{|c|}{ Yüzde } \\
\hline $2-5$ y1l & 45 & 11,1 \\
\hline $5-10$ y1l & 74 & 18,3 \\
\hline $10-20$ y1l & 137 & 33,9 \\
\hline 20 y1l ve daha fazla & 146 & 36,1 \\
\hline Cevaps1z & 2 & 0,5 \\
\hline Toplam & $\mathbf{4 0 4}$ & $\mathbf{1 0 0}$ \\
\hline
\end{tabular}

Tablo 4 incelendiğinde araştırmaya katılan meslek mensuplarının \%36,1'lik bir oranla 20 yıl ve daha fazla mesleki tecrübeye sahip olduğu görülmektedir. Daha sonra sirasiyla cevaplayıcıların mesleki tecrübelerini ifade edersek; \%33,9'luk kısmı 10-20 yıl, $\% 18,3$ 'lük kısmı 5-10 yıl ve son olarak \%11,1'lik kısmı ise 2-5 yıl arasında mesleki tecrübeye sahip olduğu görülmektedir. Araştırmaya katılanların $\% 0,5$ 'i ise mesleki tecrübelerini belirtmemiştir. Bu sonuçla birlikte araştırmada kullanılan verilerin, tecrübeli kişiler tarafından oluşturulduğu söylenebilir.

Araştırmaya katılan muhasebe meslek mensuplarının eğitim durumu dağglımı, Tablo 5' de verilmiştir. Buna göre; meslek mensuplarının 39'u lise, 13'ü ön lisans, 285 'i lisans ve 65 'i lisansüstü eğitim almışlardır. 
Tablo 5. Araştırmaya Katılanların Eğitim Durumları

\begin{tabular}{|l|l|l|}
\hline \multicolumn{1}{|c|}{ Eğitim Durumu } & \multicolumn{1}{|c|}{ Sayı } & Yüzde \\
\hline Lise & 39 & 9,7 \\
\hline Ön Lisans & 13 & 3,2 \\
\hline Lisans & 285 & 70,5 \\
\hline Lisansüstü & 65 & 16,1 \\
\hline Cevapsız & 2 & 0,5 \\
\hline Toplam & $\mathbf{4 0 4}$ & $\mathbf{1 0 0}$ \\
\hline
\end{tabular}

Tablo 5 incelendiğinde araştırmaya katılanların büyük çoğunluğunun \%70,5'lik bir oranla lisans mezunu olduğu görülmektedir. Daha sonra sırasıyla; $\% 16,1^{\prime}$ lik oranla lisansüstü, 9,7'lik oranla lise ve $\% 3,2^{\prime}$ lik oranla ön lisans mezunu oldukları tespit edilmiştir. Araştırmaya katılanların \%0,5’i eğitim durumlarını belirtmemiştir.

Araştırmaya katılan meslek mensuplarının kurumsal yönetim uygulaması hakkındaki bilgi düzeyleri Tablo 6’ da görüldüğ̈̈ gibidir.

Tablo 6 incelendiğinde; "Kurumsal yönetim uygulamaları hakkında bilgi sahibi misiniz?" sorusuna \%74,3'lük oranla, "Kurumsal yönetim uygulamaları şirketler için önemli midir?" sorusuna \%86,1'lik oranla ve "Kurumsal yönetim anlayışı ve ilkeleri (SPK ve OECD Kurumsal Yönetim İlkeleri, İMKB düzenlemeleri) sizce şirketlerce uygulanmalı mıdır?" sorusuna ise $\% 83,7^{\prime}$ lik oranla evet cevabının verildiği görülmektedir.

Muhasebeciler belli kişi ve grupların değil, tüm toplumun çıkarlarını gözetmelidirler. Toplumun çıkarlarını gözetirken kurumsal yönetim ilkelerine uygun hareket etmelidirler. Kurumsal yönetimin gelişmesi ve uygulanmasının yaygınlaştırılması için muhasebe meslek mensuplarının adil davranma, hesap verebilirlik, sorumluluk ile kamuyu aydınlatma ve şeffaflık kavramlarını bilmeleri ve önem vermeleri gerekmektedir. Tablo 6' da belirtilen sonuçlara göre; araştırmacıların büyük bir çoğunluğunun kurumsal yönetim bilgi düzeylerinin yüksek olduğu görülmektedir.
Bu konuyla ilgili, "Muhasebe meslek mensuplarının mesleki tecrübeleri ile kurumsal yönetim uygulamaları hakkında bilgi sahibi olma durumları arasında ilişki yoktur." şeklinde oluşturulan hipotez 'in değerlendirilmesi için; belirtilen yokluk hipotezi test edilecektir.

Muhasebe meslek mensuplarının mesleki tecrübeleri ile kurumsal yönetim uygulamaları hakkında bilgi sahibi olma durumları arasındaki ilişkinin test edilmesinde, iki farklı örneklem söz konusu olduğundan Ki-Kare Bağımsızlık Testi kullanılmıştır. Ki-Kare Bağımsızlık Testi, iki veya daha fazla değişken grup arasında ilişki bulunup bulunmadığı inceler. Bu testin yapılabilmesi için gözlem sonuçlarının sınıflandırılmış veya gruplandırılmış bileşik seriler şeklinde gösterilmesi gerekir (Bülbül, 2001, s. 283).

Elde edilen olasıllk $(p)$ değerine göre $(p<0,05)$ yokluk hipotezi, \%95 güvenilirlikle reddedilmiştir. Buna göre; muhasebe meslek mensuplarının mesleki tecrübeleri ile kurumsal yönetim uygulamaları hakkında bilgi sahibi olma durumları arasında ilişki vardır.

Tablo 7' den anlaşılacağı üzeri; muhasebe meslek mensuplarının mesleki tecrübeleri arttıkça, kurumsal yönetim uygulamaları hakkında bilgi düzeyleri de artmaktadır. 20 yıl ve daha fazla tecrübeye sahip muhasebe meslek mensuplarının "kurumsal yönetim uygulamaları hakkında bilgi sahibi misiniz?” sorusuna $\% 82,5^{\prime}$ lik oranla evet cevabını verme oranları en yüksektir. 
Muhasebe Meslek Mensuplarının Kurumsal Yönetim Algı Düzeylerinin Ölçülmesine Yönelik Ankara Illinde Bir Araştırma

Tablo 6. Kurumsal Yönetim Bilgi Düzeyleri

\begin{tabular}{|c|c|c|c|}
\hline Kurumsal Yönetim Bilgi Düzeyleri & Cevap & Sayı & Yüzde \\
\hline \multirow{4}{*}{ Kurumsal yönetim uygulamaları hakkında bilgi sahibi misiniz? } & Evet & 300 & 74,3 \\
\hline & Hayır & 98 & 24,3 \\
\hline & Cevapsiz & 6 & 1,5 \\
\hline & Toplam & 404 & 100 \\
\hline \multirow{5}{*}{ Kurumsal yönetim uygulamaları şirketler için önemli midir? } & Evet & 348 & 86,1 \\
\hline & Hayır & 8 & 2 \\
\hline & Fikrim Yok & 42 & 10,4 \\
\hline & Cevapsiz & 6 & 1,5 \\
\hline & Toplam & 404 & 100 \\
\hline \multirow{4}{*}{$\begin{array}{l}\text { Kurumsal yönetim anlayışı ve ilkeleri (SPK ve OECD } \\
\text { Kurumsal Yönetim İlkeleri, İMKB düzenlemeleri) sizce } \\
\text { şirketlerce uygulanmalı mıdır? }\end{array}$} & Evet & 338 & 83,7 \\
\hline & Hayır & 55 & 13,6 \\
\hline & Cevapsiz & 11 & 2,7 \\
\hline & Toplam & 404 & 100 \\
\hline
\end{tabular}

Tablo 7. Mesleki Tecrübeleri ile Kurumsal Yönetim Bilgi Düzeyleri

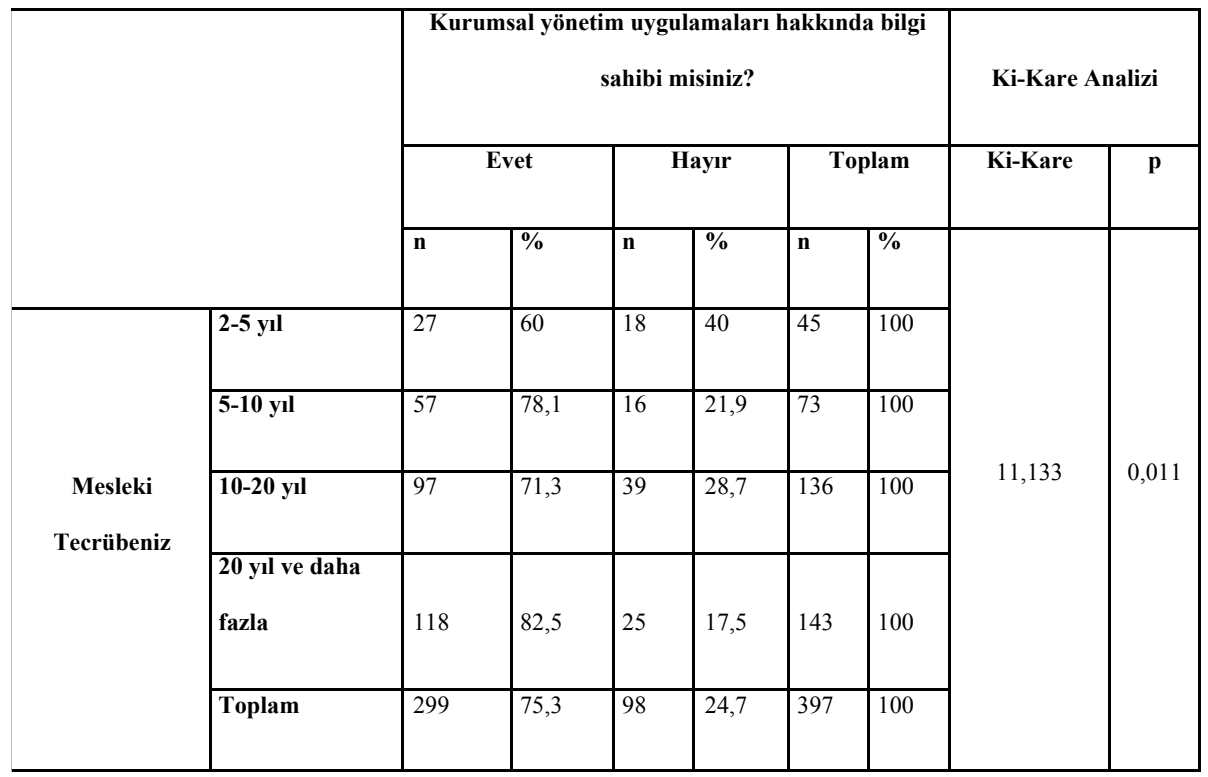




\section{Sonuç ve Öneriler}

İşletmelerde etkili bir kurumsal yönetim sisteminin kurulup geliştirilmesi büyük ölçüde muhasebe meslek mensuplarının kurumsal yönetim ilkelerine uyumu ile mümkündür. Kurumsal yönetim ilkelerini dikkate alarak gerçekleştirilen muhasebe mesleği kurumsal yönetim faaliyetlerine doğrudan katkı sağlamaktadır.

Ankara ilinde faaliyet gösteren Serbest Muhasebeci, Serbest Muhasebeci Mali Müşavir ve Yeminli Mali Müşavir meslek mensuplarına yapılan ampirik çalı̧̧ma ile bulunan sonuçlar aşağıda sunulmuştur:

- Araştırmaya katılan meslek mensuplarının büyük çoğunluğunu, meslek tecrübeleri 20 yil ve daha fazla tecrübeye sahip kişiler oluşturmaktadır.

- Araştırmaya katılanların büyük bir çoğunluğunun kurumsal yönetim bilgi düzeylerinin yüksek olduğu tespit edilmiştir.

- Muhasebe meslek mensuplarının mesleki tecrübeleri arttıkça, kurumsal yönetim uygulamaları hakkında bilgi düzeyleri de artmaktadır.

- Meslek mensuplarının mükelleflerinin kurumsal yönetime önem vermedikleri tespit edilmiştir.

Muhasebe meslek mensuplarının, kurumsal yönetim ile ilgili mevzuatı ve sorumluluklarını bilmeleri için, TÜRMOB’a bağlı Serbest Muhasebeci Mali Müşavirler Odaları ve Yeminli Mali Müşavirler Odaları tarafından eğitimler düzenlenmelidir.

Muhasebe bilgi sisteminden üretilen tam, doğru, anlaşılır, tarafsız ve güvenilir bilgiler, kurumsal yönetim anlayışının işletmelerde uygulanması için önemlidir. Bu özelliklerde muhasebe bilgisi üretebilmek için, ülkemizde iyi bir açıklama ve denetim düzeninin kurulması gerekmektedir. Muhasebe sisteminin kurumsal kimlikle ele alınması gerekmektedir.

\section{Kaynakça}

Aguilera, R. (2005). Corporate Governance and Director Accountability: An Institutional Comparative Persfective. British Journal of Management, Vol:16, 39-53. doi: 10.1111/j.1467-8551.2005.00446.x
Atabey, A. Yllmaz, B. \& Ay, M. (2005). Muhasebenin Sosyal Sorumluluk Kavramı Açısından Kurumsal Yönetim, 4.Orta Anadolu İşletmecilik Kongresi, Ankara: TOBB Ekonomi ve Teknoloji Üniversitesi.

Aysan, A, M. (2007). Kurumsal Yönetim ve Risk, İstanbul: Elit Ofset Matbaacilık.

Darman Manisalı, G. (2008). Küresel Ekonomilerde Kurumsal Yönetim Anlayışı ve Türkiye. Ankara: TOBB ICC Türkiye Milli Komitesi.

Daştan, A. (2010). Kurumsal Yönetim İlkeleri ve Kurumsal Muhasebe Etkileşimi. Bankacılar Dergisi, Say1:72, 3-18.

Doğan, M. (2007). Kurumsal Yönetim. Ankara: Siyasal Kitabevi.

Kayacan, M. (2006). Küreselleşen Dünyamızda Yeni Şirket Gündemi: Kurumsal Yönetim. İstanbul: Türkiye Etik Değerler Merkezi Vakfi, Yayın No:1.

OECD (2004). Kurumsal Yönetim İlkeleri. İstanbul: Tüsiad Yayınları.

Özkan, A. Güngör. Tanç, Ş \& Tanç, A. (2008). Finansal Tablo Dipnotlarının Kamuyu Aydınlatmadaki Öneminin Belirlenmesine Yönelik Bir Araştırma. Muhasebe Bilim Dünyası Dergisi, Sayı:3, 59-75

Poyraz, E. (2005). Küresel Finansal Yönetimde Kurumsal Finans Kavramı ve Önemi, Muhasebe ve Finansman Dergisi. Sayı:28, 153-159

Pulaşlı, H. (2003). Corporate Governance, Ankara: Banka ve Ticaret Hukuku Araştırma Enstitüsü

Sermaye Piyasası Kurulu (2005). Kurumsal Yönetim İlkeleri. Ankara: Sermaye Piyasası Kurulu Yayınları

Sloan, R, G. (2001). Financial Accounting and Corporate Governance: A Discussion. The Journal of Finance, Vol:32, 335-347, doi:10.1016/S0165-4101

Tuzcu, A. (2004). Halka Açık Şirketlerde Kurumsal Yönetim Anlayışı: İMKB-100 Örneği, Ankara: Turhan Kitabevi

TÜSİAD. (2002). Kurumsal Yönetim En İyi Uygulama Kodu: Yönetim Kurulunun Yapısı ve İşleyişi, Ankara: TÜSİAD Yayınları 